\title{
Changes in Emergency Department attendances before and after COVID-19 lockdown implementation: a cross sectional study of one urban NHS Hospital Trust
}

Honeyford $\mathrm{K}^{1}$, Coughlan $\mathrm{C}^{1,2}$, Nijman $\mathrm{R}^{3,4}$, Expert $\mathrm{P}^{1}$, Burcea $\mathrm{G}^{1}$, Maconochie $\mathrm{I}^{3}$, Kinderlerer $\mathrm{A}^{5}$, Cooke $\mathrm{G} \mathrm{S}^{6}$ and Costelloe $\mathrm{CE}^{1}$

${ }^{1}$ Global Digital Health Unit, School of Public Health, Department of Primary Care and Public Health, Imperial College London

${ }^{2}$ Connecting Care for Children, Department of Paediatrics, Imperial College Healthcare NHS Trust, London, UK

${ }^{3}$ Department of Paediatric Emergency Medicine, Division of Medicine, St. Mary's hospital - Imperial College NHS Healthcare Trust, London, London, London, UK

${ }^{4}$ Faculty of Medicine, Department of Infectious Diseases, Section of Paediatric Infectious Diseases, Imperial College London, UK

${ }^{5}$ St Mary's Hospital, Imperial College Healthcare NHS Trust, London, UK

${ }^{6}$ Faculty of Medicine, Department of Infectious Disease, Imperial College, London, UK 
medRxiv preprint doi: https://doi.org/10.1101/2020.07.20.20157560; this version posted July 21, 2020. The copyright holder for this preprint (which was not certified by peer review) is the author/funder, who has granted medRxiv a license to display the preprint in perpetuity. It is made available under a CC-BY-NC-ND 4.0 International license .

\section{Abstract}

Background

Emergency Department (ED) attendances have fallen across the UK since the 'lockdown' introduced on $23^{\text {rd }}$ March 2020 to limit the spread of coronavirus disease 2019 (COVID-19). We hypothesised that reductions would vary by patient age and disease type. We examined pre- and in-lockdown ED attendances for two COVID-19 unrelated diagnoses; one likely to be affected by lockdown measures (gastroenteritis) and one likely to be unaffected (appendicitis).

\section{Methods}

Retrospective cross-sectional study conducted across two EDs in one London hospital Trust. We compared all adult and paediatric ED attendances, before (January 2020) and during lockdown (March/April 2020). Key patient demographics, method of arrival and discharge location were compared. We used SNOMED codes to define attendances for gastroenteritis and appendicitis.

\section{Results}

ED attendances fell from 1129 per day before lockdown to 584 in-lockdown; 51.7\% of pre-lockdown rates. Inlockdown attendances were lowest for under-18s (16.0\% of pre-lockdown). The proportion of patients admitted to hospital increased from $17.3 \%$ to $24.0 \%$ and the proportion admitted to intensive care increased four-fold.

Attendances for gastroenteritis fell from 511 to $103 ; 20.2 \%$ of pre-lockdown rates. Attendances for appendicitis also decreased, from 144 to $41 ; 28.5 \%$ of pre-lockdown rates.

\section{Conclusion}

ED attendances fell substantially following lockdown implementation. The biggest reduction was for under-18s. We observed reductions in attendances for gastroenteritis and appendicitis. This may reflect lower rates of infectious disease transmission, though the fall in appendicitis-related attendances suggests that behavioural factors are also important. Larger studies are urgently needed to understand changing patterns of ED use and access to emergency care during the COVID-19 pandemic.

\section{What this paper adds}

- What is already known on this subject:

$\circ$ ED attendances have decreased during the COVID-19 associated lockdown.

- Various theories have been suggested for changes in ED attendance, including lower transmission of infectious diseases and patients heeding recommendations from government bodies.

- What this study adds:

$\circ \quad$ Reductions in ED attendances vary by age group and disease type.

- We propose a conceptual casual framework for underlying reasons behind changes in ED attendance in England during the COVID-19 lockdown.

- Following lockdown implementation, we observed a reduction in ED attendances with both infectious and non-infectious diseases. This suggests that reduced transmission of infectious disease is not the only cause of lower overall ED attendances. 
medRxiv preprint doi: https://doi.org/10.1101/2020.07.20.20157560; this version posted July 21, 2020. The copyright holder for this preprint (which was not certified by peer review) is the author/funder, who has granted medRxiv a license to display the preprint in perpetuity. It is made available under a CC-BY-NC-ND 4.0 International license .

\section{Introduction}

The emergence of COVID-19 and subsequent 'lockdown' introduced by the British Government on $23^{\text {rd }}$ March $2020^{1}$ has had a substantial impact on Emergency Department (ED) attendances. Total ED attendances in England in March 2020 fell by $29.4 \%$ year-on-year. ${ }^{2}$ Reasons for this change in ED activity are likely to be multifactorial. To reduce pressure on EDs, patients have been instructed to seek advice from online resources and NHS telephone services. The closure of schools and workplaces is likely to have led to a reduction in the spread of infectious diseases. ${ }^{2}$ Reductions in organised sports and recreational activity will be associated with reductions in physical injuries. ${ }^{3}$ It is suggested that reductions in children attending EDs reflect parents' concerns about acquiring infection in hospital settings. ${ }^{4}$

We hypothesised that the impact of the nationwide lockdown on ED attendance would vary by patient demographics and clinical reason for attendance. We have proposed causal pathways leading to changes in ED attendances and hospital admissions. These are summarised in Figure 1. Using a snapshot of ED data, we examined the number of pre- and in-lockdown ED attendances for two COVID-19 unrelated diagnoses:

- Gastroenteritis - an infectious disease which we would expect to be affected by lockdown measures.

- Appendicitis - an acute disorder which we would expect to be largely unaffected by lockdown measures.

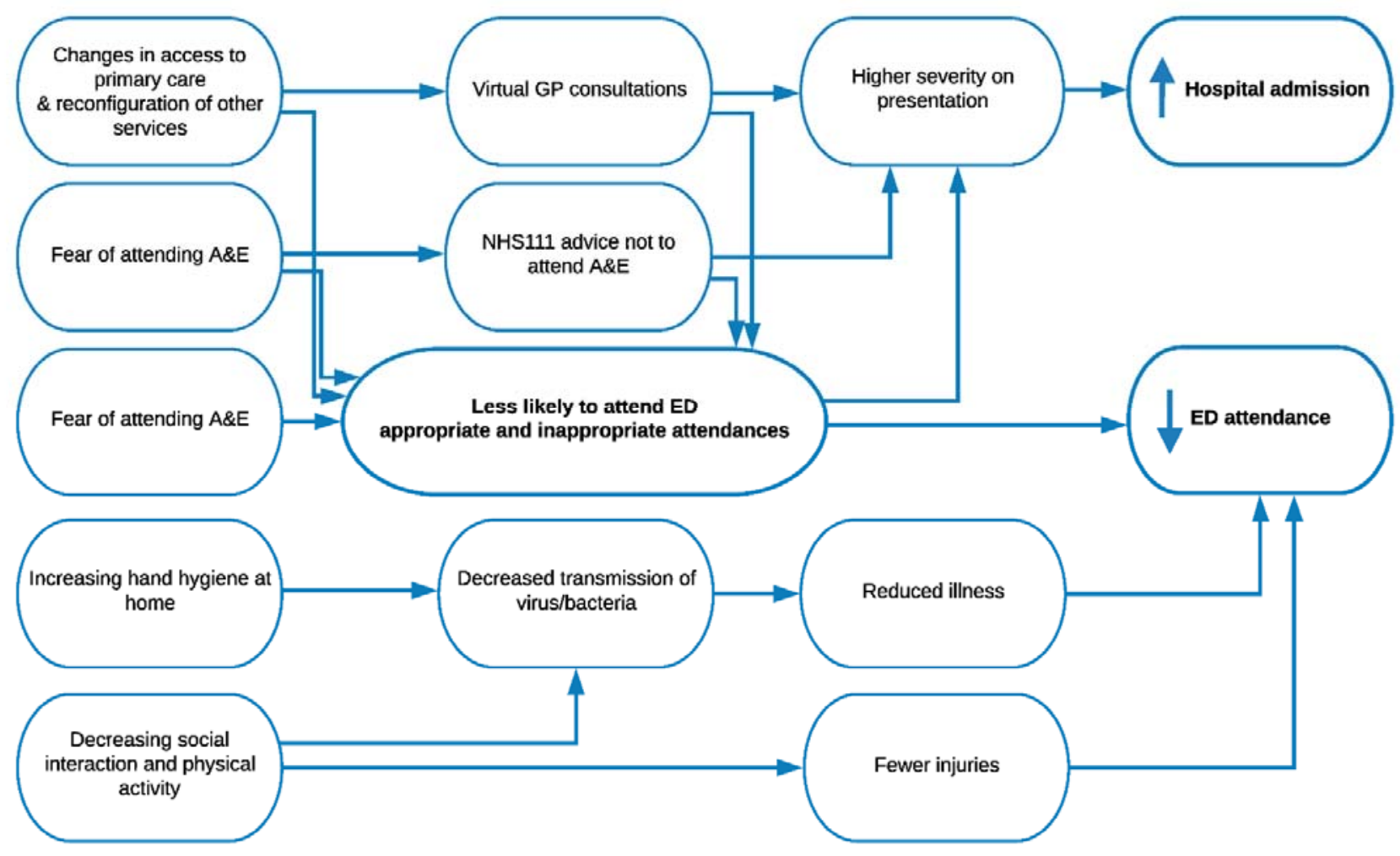

Figure 1 Conceptual framework for changes in ED attendance associated with 'lockdown' for conditions unrelated to COVID-19

\section{Methods}

ED attendance information was provided by the NHS Trust data warehouse team. Information included patient information: age, gender, ethnicity, residential partial postcode, arrival mode at ED, destination at discharge and SNOMED ${ }^{5}$ diagnostic codes.

We selected a four-week period ( $6^{\text {th }}$ January 2020 to $2^{\text {nd }}$ February 2020) as the pre COVID-19 phase and a four-week period (23 $3^{\text {nd }}$ March 2020 to $19^{\text {th }}$ April 2020) as the in-lockdown period. We included all ED attendances (children and adults).

We compared ED attendances based on patient demographics and we compared attendances for gastroenteritis and appendicitis, in total and by age, to assess examples of one diagnosis likely to be affected and one diagnosis unlikely to be affected by lockdown measures. Differences were assessed using Chi-Squared test. Analysis was done in R 
medRxiv preprint doi: https://doi.org/10.1101/2020.07.20.20157560; this version posted July 21, 2020. The copyright holder for this preprint (which was not certified by peer review) is the author/funder, who has granted medRxiv a license to display the preprint in perpetuity.

It is made available under a CC-BY-NC-ND 4.0 International license .

version 3.60. This study was granted service evaluation approval through Imperial College London NHS Trust (Ref:228). Patients or the public were not involved in the design, or conduct, or reporting, or dissemination plans of our research.

\section{Results}

There were 31,624 ED attendances in the pre-lockdown period and 16,355 in-lockdown; a reduction from 1129 attendances a day pre-lockdown, to 584 a day in-lockdown. Arrivals in ambulances accounted for $61.2 \%$ attendances pre- and $51.7 \%$ in-lockdown. As a proportion of pre-lockdown attendances, in-lockdown attendances were lowest for under-18s (16.0\%) and highest for patients aged 40-60 (76.7\%). Male and Asian patients made up a higher proportion of in-lockdown than pre-lockdown attendances. This was also true for patients from postcodes considered the primary catchment for the Trust (77\% pre-lockdown and $80 \%$ in lockdown). Pre-lockdown, $17.5 \%$ of ED attendances resulted in admission to inpatient wards or intensive care units (ICUs), compared to $24.4 \%$ inlockdown. Following lockdown implementation, $4 \%$ of admitted patients were admitted directly to ICU, compared to 1\% pre-lockdown. Results are summarised in Table 1.

\begin{tabular}{|c|c|c|c|c|c|}
\hline \multicolumn{3}{|c|}{ Time period } & \multirow{2}{*}{$\begin{array}{l}\text { Pre-lockdown } \\
\text { n (\% of all attendances) }\end{array}$} & \multicolumn{2}{|l|}{ In-lockdown } \\
\hline & & & & $\begin{array}{l}\mathrm{n} \text { (\% of all } \\
\text { attendances) }\end{array}$ & $\begin{array}{l}\text { as } \% \text { of pre-lockdown } \\
\text { attendance }\end{array}$ \\
\hline \multicolumn{3}{|c|}{ Total number of attendances } & 31,624 & 16,355 & $51.7 \%$ \\
\hline Male & & & $15,359(48.6 \%)$ & $8870(52.9 \%)$ & $57.8 \%$ \\
\hline \multirow{7}{*}{ Age } & \multicolumn{2}{|l|}{$0-18$} & $7054(22.2 \%)$ & $1131(6.8 \%)$ & $16.0 \%$ \\
\hline & \multicolumn{2}{|l|}{$18-40$} & $8412(26.6 \%)$ & $4865(29.0 \%)$ & $57.8 \%$ \\
\hline & \multicolumn{2}{|l|}{$40-50$} & $3073(9.7 \%)$ & $2368(14.1 \%)$ & $77.1 \%$ \\
\hline & \multicolumn{2}{|l|}{$50-60$} & $3616(11.4 \%)$ & $2702(16.1 \%)$ & $74.7 \%$ \\
\hline & \multicolumn{2}{|l|}{$60-70$} & $2922(9.2 \%)$ & $1868(11.1 \%)$ & $63.9 \%$ \\
\hline & \multicolumn{2}{|l|}{$70-85$} & $4563(14.4 \%)$ & $2797(16.7 \%)$ & $61.3 \%$ \\
\hline & \multicolumn{2}{|l|}{$85+$} & $1984(6.3 \%)$ & $1034(6.2 \%)$ & $52.1 \%$ \\
\hline Ethnic & \multicolumn{2}{|c|}{ Any other ethnic group } & $7704(24.4 \%)$ & $3787(22.6 \%)$ & $49.2 \%$ \\
\hline & \multicolumn{2}{|l|}{ White } & $12576(39.8 \%)$ & $6342(38.8 \%)$ & $50.4 \%$ \\
\hline & \multicolumn{2}{|c|}{ Black or Black British } & $4256(13.5 \%)$ & $2239(13.7 \%)$ & $52.6 \%$ \\
\hline & \multicolumn{2}{|l|}{ Asian } & $1499(4.7 \%)$ & $1208(7.2 \%)$ & $80.6 \%$ \\
\hline & \multicolumn{2}{|l|}{ Not stated } & $3445(10.9 \%)$ & $2154(12.9 \%)$ & $62.5 \%$ \\
\hline & \multicolumn{2}{|l|}{ Not known } & $547(1.7 \%)$ & $594(3.5 \%)$ & $108.6 \%$ \\
\hline \multicolumn{3}{|c|}{ Catchment Area } & $24,568(77.7 \%)$ & $13,467(80.3 \%)$ & $54.8 \%$ \\
\hline \multicolumn{3}{|c|}{ Arrival by Ambulance } & $19,340(61.2 \%)$ & $7972(51.70 \%)$ & $41.2 \%$ \\
\hline \multicolumn{4}{|c|}{ Discharge destination } & & \\
\hline \multicolumn{2}{|l|}{ Home $^{1}$} & \multicolumn{2}{|c|}{$20935(66.2 \%)$} & $10930(66.8 \%)$ & $52.2 \%$ \\
\hline \multicolumn{2}{|c|}{ Admitted to hospital } & \multicolumn{2}{|c|}{$5463(17.3 \%)$} & $3921(24.0 \%)$ & $71.8 \%$ \\
\hline \multicolumn{2}{|c|}{ Other hospital care ${ }^{2}$} & \multicolumn{2}{|c|}{$3945(12.5 \%)$} & $798(4.9 \%)$ & $20.2 \%$ \\
\hline \multicolumn{2}{|c|}{ Mortuary } & \multicolumn{2}{|c|}{$38(0.1 \%)$} & $69(0.4 \%)$ & $181.6 \%$ \\
\hline \multicolumn{2}{|c|}{ Missing } & \multicolumn{2}{|c|}{$259(0.8 \%)$} & $619(3.7 \%)$ & $239.0 \%$ \\
\hline \multicolumn{6}{|c|}{ Disease Profile } \\
\hline Gastroe & itis & 511 & & $103(0.6 \%)$ & $20.2 \%$ \\
\hline Appenc & & 144 & & $41(0.3 \%)$ & $28.5 \%$ \\
\hline
\end{tabular}

${ }^{1:}$ Home includes nursing and residential care homes.

${ }^{2:}$ Other hospital care includes ambulatory care centre and short stay wards

Table 1 Characteristics of patients attending two EDs in one hospital trust in North West London, $p<0.0001$ for all pre vs in-lockdown comparisons. 
medRxiv preprint doi: https://doi.org/10.1101/2020.07.20.20157560; this version posted July 21, 2020. The copyright holder for this preprint (which was not certified by peer review) is the author/funder, who has granted medRxiv a license to display the preprint in perpetuity. It is made available under a CC-BY-NC-ND 4.0 International license .

\section{Gastroenteritis and appendicitis attendances pre- and in-lockdown}

Pre-lockdown, there were 511 attendances with a gastroenteritis code, 1.62\% of all attendances, compared to 103 attendances in-lockdown, $0.61 \%$ of the total. Total ED attendances with an appendicitis code also decreased over the study period, from 144 (0.46\% total) to 41 (0.24\% total). Attendances for gastroenteritis in-lockdown were $20.2 \%$ of pre-lockdown, compared to $28.5 \%$ for appendicitis. While a similar proportion of patients with gastroenteritis were directly discharged home in both time periods, we observed a three-fold increase in discharge rates among patients with appendicitis following lockdown implementation.

Changes in attendances for both diseases varied with age (Figure 2). We observed the most significant reduction in attendances with gastroenteritis amongst children and young people and patients aged over 60 .

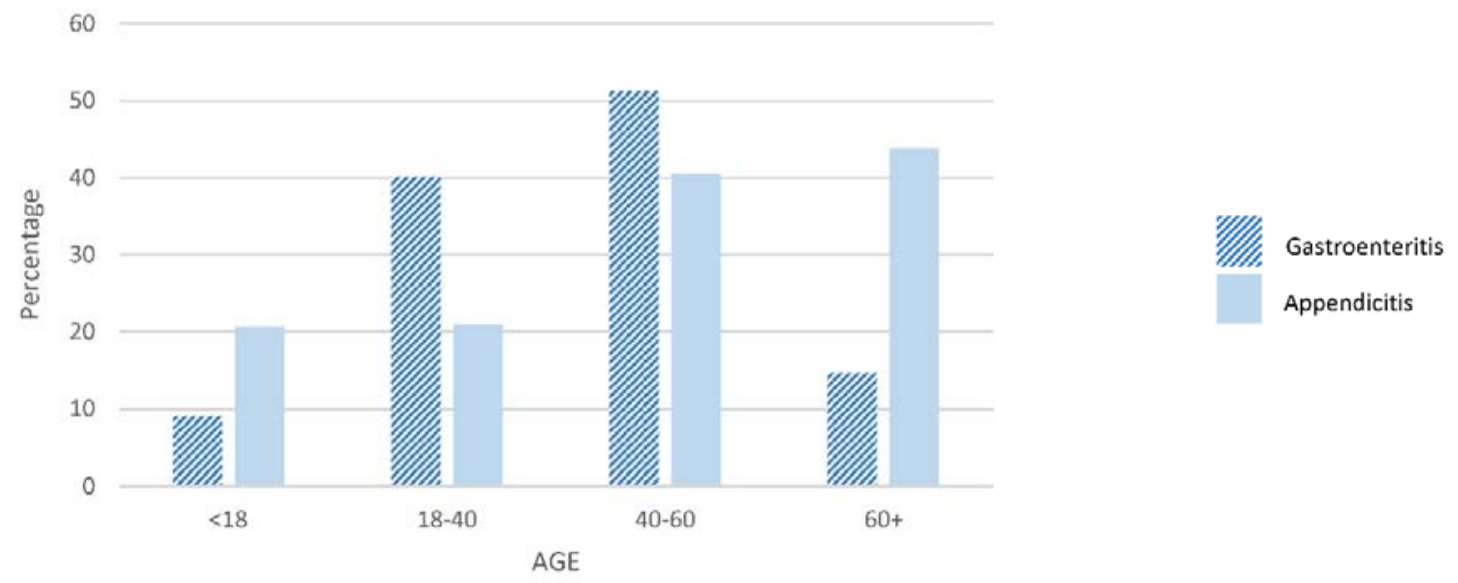

Figure 2 ED attendances for gastroenteritis and appendicitis, by age, post-lockdown-implementation as a percentage of pre-lockdown attendances.

\section{Discussion}

In line with national data ${ }^{2}$, we have found that overall ED attendances have almost halved since the introduction of lockdown. Similar to other reports ${ }^{6}$ the impact of the lockdown on ED attendance rate was greatest in the under$18^{\prime}$ s, suggesting changes in parental health-seeking behaviour.

Following lockdown implementation, a higher proportion of ED patients required hospital admission and there was a four-fold increase in the proportion admitted directly to ICU. These changes may reflect patients attending with more serious conditions, severe COVID-19 and/or the increase in ICU capacity.

We hypothesised a reduction in gastroenteritis-related attendances following lockdown implementation due to reduced interpersonal contact and spread of infectious diseases. The results show that attendances in-lockdown fell to one fifth of pre-lockdown rates. A reduction in ED attendances for specific infectious diseases has been described in England ${ }^{2}$ and Italy. ${ }^{7}$ However, the decrease in attendances for appendicitis suggests that reduced transmission alone cannot explain the reduction in ED attendances seen after lockdown.

Not all of the differences we have reported are attributable to lockdown Seasonal variations are seen in a range of infectious diseases, including gastroenteritis. Nationally published data for this hospital Trust suggests April attendances in 2019 were only $5 \%$ lower than January 2019. ${ }^{8}$ Patients with COVID-19 may present with diarrhoea and vomiting ${ }^{9}$ and this may confound gastroenteritis coding. Some attendances will be due to COVID-19; we did not exclude these as it's impossible to know patients' motivation for atten ding the ED and testing policy evolved over time. Treatment pathways have changed during the pandemic as hospitals have sought to minimize non-emergency surgery. This includes an increase in the management of uncomplicated appendicitis with oral antibiotics possibly explaining the fall in appendicitis-related admissions. ${ }^{10}$

We have developed a conceptual causal framework proposing various factors which may lead to lower ED attendances during the COVID-19 pandemic. These factors include deterred care seeking due to fears of acquiring 
medRxiv preprint doi: https://doi.org/10.1101/2020.07.20.20157560; this version posted July 21, 2020. The copyright holder for this preprint (which was not certified by peer review) is the author/funder, who has granted medRxiv a license to display the preprint in perpetuity. It is made available under a CC-BY-NC-ND 4.0 International license .

infection in hospital settings and patients seeking health advice from other services. Future studies, using larger, more generalisable data must aim to untangle the relative contributions of these different factors and ensure that sick patients have timely and equitable access to Emergency Care. 
medRxiv preprint doi: https://doi.org/10.1101/2020.07.20.20157560; this version posted July 21, 2020. The copyright holder for this preprint (which was not certified by peer review) is the author/funder, who has granted medRxiv a license to display the preprint in perpetuity. It is made available under a CC-BY-NC-ND 4.0 International license .

\section{References}

1 https://www.parliament.uk/business/news/2020/march/update-on-coronavirus-24-march-2020

2 Kelly E \& Firth Z How is COVID-19 changing the use of emergency care? The Health Foundation. 15 May 2020. Available from: www. health.org.uk/news-and-comment/charts-and-infographics/how-is-covid-19changing-the-use-of-emergency-care. Accessed: $5^{\text {th }}$ June 2020.

3 Buddhdev $\mathrm{P}$, Gille $\mathrm{H}$ and Ibrahin $\mathrm{Y}$ The paediatric burden of UK lockdown - early results in the COVID-19 era. British Orthopaedic Association (2020). Available at: https://www.boa.ac.uk/policy-engagement/journal-oftrauma-orthopaedics/journal-of-trauma-orthopaedics-and-coronavirus/the-paediatric-trauma-burden-of-uklockdown-early.html Accessed: $9^{\text {th }}$ June 2020

$4 \quad$ Wong LE, Hawkins JE, Langness S et al. Where Are All the Patients? Addressing Covid-19 Fear to Encourage Sick Patients to Seek Emergency Care | Catalyst non-issue content [Internet]. Catalyst.nejm.org. 2020. Available from: https://catalyst.nejm.org/doi/full/10.1056/CAT.20.0193 Accessed 9th June 2020

5 NHS Digital SNOMED CT 2020 Available from:https://digital.nhs.uk/services/terminology-andclassifications/snomed-ct Accessed $9^{\text {th }}$ June 2020

6 Isba R, Edge R, Jenner R, et al Where have all the children gone? Decreases in paediatric emergency department attendances at the start of the COVID-19 pandemic of 2020 Archives of Disease in Childhood Published Online First: 06 May 2020. doi: 10.1136/archdischild-2020-319385

7 Angoulvant F, Ouldali N, Dawei Yang D et al COVID-19 Pandemic: Impact Caused by School Closure and National Lockdown on Pediatric Visits and Admissions for Viral and Non-Viral Infections, a Time Series Analysis. 202 Clinical Infectious Diseases. https://doi.org/10.1093/cid/ciaa710.

8 NHS England. A\&E Attendances 2020 Available from: www.england.nhs.uk/statistics/statistical-workareas/ae-waiting-times-and-activity/ Accessed $5^{\text {th }}$ June 2020

9 Jin X, Lian J, Hu J, et al. Epidemiological, clinical and virological characteristics of 74 cases of coronavirusinfected disease 2019 (COVID-19) with gastrointestinal symptoms. Gut 2020 https://gut.bmj.com/content/69/6/1002

Collard M, Lakkis Z, Loriau J, et al J Visc Surg. Antibiotics alone as an alternative to appendectomy for uncomplicated acute appendicitis in adults: Changes in treatment modalities related to the COVID-19 health crisis 2020 Apr 24 doi: $10.1016 /$ i.jviscsurg.2020.04.014 [Epub ahead of print] 
medRxiv preprint doi: https://doi.org/10.1101/2020.07.20.20157560; this version posted July 21, 2020. The copyright holder for this preprint (which was not certified by peer review) is the author/funder, who has granted medRxiv a license to display the preprint in perpetuity. It is made available under a CC-BY-NC-ND 4.0 International license .

\section{FUNDING}

This report is independent research funded by the UK National Institute for Health Research (NIHR) Biomedical Research Centre NIHR-BRC-P68711. KH and PE are supported by the NIHR Imperial Biomedical Research Centre (BRC). CC is supported by a personal NIHR Career Development Fellowship (NIHR-2016-090-015). GSC is supported by NIHR Research Professorship. RGN is supported by NIHR academic clinical lecturer award (ACL-2018-21-007). ChC's work as a Clinical Research Fellow in Integrated Care is supported by a grant from the Imperial Health Charity. Ethics for this study was granted service evaluation approval through Imperial College London NHS Trust (Ref:228)

\section{AUTHOR CONTRIBUTIONS}

$\mathrm{KH}, \mathrm{CC}, \mathrm{RN}, \mathrm{ChC}$ and PE conceived the study and developed the protocol. $\mathrm{KH}$ conducted the statistical analysis, which was reviewed and improved by $\mathrm{PE}, \mathrm{GB}$ and $\mathrm{CC}$. GSC, RN, ChC, IM and AK provided ongoing feedback on results and their interpretation. $\mathrm{KH}$ wrote the first draft of the manuscript. All authors reviewed and contributed to the final draft of the manuscript. CC is the guarantor. KH attests that all listed authors meet authorship criteria and that no others meeting the criteria have been omitted. The views expressed are those of the author(s) and not necessarily those of the National Health Service, National Institute for Health Research, or the Department of Health and Social Care.

\section{ACKNOWLEDGMENTS}

This research was funded by the NIHR Imperial Biomedical Research Centre (BRC). The research was conducted using National Institute of Health Research Health Informatics Collaborative data resources. The views expressed are those of the authors and not necessarily those of the NIHR or the Department of Health and Social Care.

Imperial College London is grateful for support from the NW London NIHR Applied Research Collaboration. The views expressed in this publication are those of the authors and not necessarily those of the NIHR or the Department of Health and Social Care 